\title{
Survival of Fusarium solani f. sp. cucurbitae and Fungicide Application, Soil Solarization, and Biosolarization for Control of Crown and Foot Rot of Zucchini Squash
}

\author{
Ana Pérez-Hernández, Elena Porcel-Rodríguez, and Julio Gómez-Vázquez, IFAPA Centro La Mojonera, 04745 La Mojonera, Almería, \\ Spain
}

\begin{abstract}
Fusarium crown and foot rot of zucchini squash (Cucurbita pepo L.) caused by Fusarium solani f. sp. cucurbitae is one of the major diseases affecting zucchini squash production in Almería, Spain. Experiments were conducted to determine the pathogen's ability to survive in infested bags of perlite and to test several control methods under greenhouse conditions. The pathogen survived in the bags for at least 20 months with enough inoculum at that time to produce disease symptoms in zucchini plants, although disease severity was significantly reduced after 14 months. A total of 14 zucchini cultivars were inoculated with $F$. solani f. sp. cucurbitae, and all were highly susceptible to the disease. Eight fungicides and two microbial products, Trichoderma harzianum and Rhizophagus

irregularis, were tested to determine their efficacy for the control of this disease. Prochloraz, carbendazim, and thiophanate-methyl, which are not labeled for use in zucchini in Spain, were highly effective for the control of the disease, while the other products were ineffective. Two soil solarization and biosolarization experiments were conducted in a greenhouse for 45-day periods during the summer. Inocula in the soil samples decreased by more than $99 \%$, indicating the efficacy of completely closing the greenhouse windows, solarization, and biosolarization in reducing inoculum. Fungicide applications, crop rotation for at least two years, and soil solarization or biosolarization are promising control methods for this disease.
\end{abstract}

Zucchini squash (Cucurbita pepo L.) is a predominant crop grown in Almería Province, southeastern Spain, where the largest concentration of greenhouses worldwide is found. In 2014, 7,116 ha of greenhouse space were used to produce 347,160 metric tons of zucchini squash. This production accounts for $74.7 \%$ of the total production in Spain, making it one of the most economically important crops for this country (Spanish Ministry of Agriculture, Food and Environment, MAGRAMA, 2015).

In this area, around $80 \%$ of crops are grown in a soil management system known as "enarenado." It consists of adding to the soil surface a 10 to $15-\mathrm{cm}$ layer of siliceous sand with a particle size of less than $3 \mathrm{~mm}$ in diameter. This sand layer helps increase the soil temperature in the coldest months, retains the irrigated water for a longer period of time, avoids the concentration of salts near the rhizosphere, and promotes aeration and superficial root development (Valera et al. 2014, Wolosin 2008). Another important crop system in the region is the use of soilless culture, used by almost $14 \%$ of growers, in which the most commonly used substrates are perlite and coco peat (Valera et al. 2014). Soilless cultures provide some advantages, such as greater production of crops, reduced energy consumption, better control of growth, and independence of soil quality (Vallance et al. 2011).

In 2008, a new fungal disease of zucchini squash was reported in Almería Province (Gómez et al. 2008) and was found to be caused by F. solani (Mart.) Sacc. f. sp. cucurbitae W. C. Snyder and H. N. Hansen. The high incidence in the affected greenhouses and the aggressiveness of this pathogen had a large economic impact on growers. Since its detection, Fusarium crown and foot rot of zucchini squash has spread rapidly within the province and to other

Corresponding author: Ana Pérez-Hernández; E-mail: anaperezh@ gmail.com

Disclaimer: Mention of trade names or commercial products in this publication is solely for the purpose of providing specific information and does not necessarily imply recommendation by the IFAPA.

*The $\boldsymbol{e}$-Xtra logo stands for "electronic extra" and indicates that one supplementary figure is published online.

Accepted for publication 2 April 2017.

(c) 2017 The American Phytopathological Society cucurbits, such as melon (Gómez et al. 2014) and watermelon (Porcel 2013).

Fusarium solani f. sp. cucurbitae has a host specificity for cucurbits (Boughalleb et al. 2007; Messiaen et al. 1995; Paternotte 1987). This pathogen has been reported to cause disease in pumpkin (Matta and Garibaldi 1981), muskmelon (Champaco et al. 1993), cucumber (Bourbos et al. 1997), watermelon, and rootstock hybrids of Cucurbita maxima $\times$ Curcurbita moschata (Armengol et al. 2000), among others. In addition, it has been demonstrated that the pathogen can be transmitted by seed, at least in watermelon and pumpkin seeds (Boughalleb and El Mahjoub 2006; Mehl and Epstein 2007).

Genetic resistance against this pathogen has not been found, and the most common control method for the disease caused by $F$. solani f. sp. cucurbitae is the rotation of crops with nonhosts (i.e., plants not belonging to the cucurbit family) for 3 or 4 years (Zitter et al. 1996). However, there are few reports on the survival of $F$. solani f. sp. cucurbitae in the soil or in substrates after a disease occurrence. Some plantpathogenic Fusaria produce chlamydospores that permit the survival of the organism in the soil. Although $F$. solani f. sp. cucurbitae produces chlamydospores, these seem to be less suited for survival than those of other Fusarium species, such as F. solani f. sp. phaseoli (Nash and Alexander 1965). In the Almería region, it is common to reuse the substrates used for soilless cultures for several years in order to improve crop profitability (Bonachela et al. 2008), and usually parts of the roots from previous crops remain in the bags. Elucidation of the survival of this pathogen after a disease incidence in the substrates would provide useful information for the implementation of a good management strategy.

There is a lack of research on the efficacy of available products for the chemical control of this disease. Sultana and Ghaffar (2010) demonstrated an inhibition of the growth of $F$. solani on potato dextrose agar (PDA) supplemented with the fungicides fosetyl-Al, benomyl, carbendazim, mancozeb, metalaxyl-m, thiophanate-methyl, and carboxin with concentrations greater than $500 \mathrm{ppm}$. They were also able to inhibit infection in bitter gourd plants (Momordica charantia) grown from naturally infested seeds by treating them with benomyl and carbendazim. In addition, Ben Salem et al. (2011) achieved total inhibition of the in vitro growth of $F$. solani in culture media amended with the fungicides hymexazol, carbendazim, and thiophanate-methyl. However, despite evidence of the efficacy of these chemicals for the control of zucchini crown and foot rot caused by $F$. solani f. sp. 
cucurbitae, some of them are subjected to restrictions for their use in cucurbit crops. For example, benomyl's registration for agricultural use was cancelled in the last decade in the United States (EPA-738-R-02-011, Environmental Protection Agency 2002), the European Union (2002/928/EC, European Communities 2002), and other countries.

There are few reports regarding the biocontrol of this disease. Recently, several commercial microbial products containing various species of Trichoderma spp. or bacteria-like Streptomyces sp. and Pseudomonas sp. were found to reduce the severity of Fusarium crown and foot rot of zucchini squash (Roberti et al. 2012), establishing the potential of these microorganisms for controlling this disease, as well as the need for further research into microbial antagonists as biocontrol agents for commercial crops.

There are also cultural practices with potential for controlling this disease. Soil solarization is a technique based on the utilization of solar radiation to raise soil temperatures close to a level that may be lethal or sublethal to pathogens in moist soils using plastic mulching (Katan 1981). Its efficacy in reducing inoculum density of soilborne pathogens such as Fusarium spp. has been demonstrated in several studies (Chellemi et al. 1997; González-Torres et al. 1993; Matheron and Porchas 2010). Solarization can be performed in greenhouses by completely closing the windows to retain heat. Temperatures reached in solarized soils inside greenhouses are significantly higher than those obtained in open fields and can therefore be more effective (Elmore et al. 1997). In Greece, soil solarization in combination with calcium cyanamide and organic matter was reported to be effective at reducing $F$. solani f. sp. cucurbitae soil inoculum by $99 \%$ in greenhouse experiments (Bourbos et al. 1997). Biofumigation is yet another disinfestation method and refers to the suppression of soilborne pathogens or pests by decomposing organic materials, such as agricultural byproducts or manure. Fermentation of these materials releases volatile compounds that may have a fumigant action against plant pathogens (Bello et al. 1999). When soil solarization and biofumigation are combined, the resulting technique is known as biosolarization. This disinfestation method is relatively new and, therefore, information in the scientific literature is scarce. Recently, Martínez et al. (2011) observed a reduction in F. oxysporum, $F$. solani, and $F$. equiseti populations in greenhouse soils after repeated biosolarization treatments with diminishing doses of manure and pepper crop residues. In addition, Núñez-Zofio et al. (2011) demonstrated a high reduction in the oospore viability of Phytophthora capsici in greenhouse pepper (Capsicum annuum) crops after applying organic amendments followed by soil plastic mulching.

On the basis of its ability to produce chlamydospores, we hypothesized that $F$. solani $\mathrm{f}$. sp. cucurbitae would survive in the soil and in soilless substrates after a disease outbreak, and a control strategy would be needed to avoid occurrence of this disease in future crops. The objectives of this study were to examine (i) the survival of the fungus in artificially infested bags of perlite and (ii) the efficacy of five possible control methods for Fusarium crown and foot rot of zucchini squash: host resistance; chemical control; biological control; soil solarization; and soil biosolarization.

\section{Materials and Methods}

Isolate identification. An isolate of $F$. solani $\mathrm{f}$. sp. cucurbitae (PCl-511), which was collected in 2009 from zucchini in a commercial greenhouse in Almería Province and whose pathogenicity on zucchini plants grown on bags of perlite was previously demonstrated (Porcel 2013), was used for the experiments. A pure culture was isolated from a single conidium and identified based on morphological and molecular characteristics. Polymerase chain reaction (PCR) amplification of the translation elongation factor 1- $\alpha$ (TEF $1-\alpha$ ) using primers EF1 (5'-ATGGGTAAGGA(A/G)GACAAGAC$\left.3^{\prime}\right)$ and EF2 (5'-GGA(G/A)GTACCAGT(G/C)ATCATGTT-3') was purified and submitted to the Universitat Politecnica de Valencia (Spain) for sequencing. Both DNA strands of the TEF1- $\alpha$ gene were sequenced. The resulting sequence of the isolate was compared with those available in GenBank, and the sequence had 100\% homology with GenBank Accession No. DQ986152, corresponding to Nectria haematococca mpI. This sequence was submitted as GenBank Accession No. KF372878.

Production of pathogen inoculum. For every experiment, plates with the isolate were produced on PDA medium. PDA was prepared by mixing infusion of potatoes $(200 \mathrm{~g}), 20 \mathrm{~g}$ of dextrose, and $17 \mathrm{~g}$ of agar per liter. Plates were incubated under indirect natural light at $25^{\circ} \mathrm{C}$ and maintained between 15 and 20 days until they were completely colonized. Conidial suspensions were prepared by scraping the surface of the plates with a sterile loop and recovered by washing the plates with autoclaved water. The inoculum was then filtered through a 0.5 -mm-opening mesh to remove large portions of mycelia and adjusted with a Thoma cell counting chamber to an approximate concentration of $1.1 \times 10^{5}$ conidia/ml. Fifty milliliters of inoculum were poured around the basal stem of each plant. For soil solarization and biosolarization experiments, inoculum from 30 PDA plates was recovered in $200 \mathrm{ml}$ of sterile water and blended to homogenize the solution. This conidial suspension was then used to produce artificially infested soil samples.

Methods for growing plants. The experiments to assess survival of the fungus in bags of perlite, to evaluate the susceptibility of several zucchini squash cultivars, and to evaluate the efficacy of some fungicides were conducted in a $970-\mathrm{m}^{2}$, multispan polyethylene-covered greenhouse located at IFAPA Centro La Mojonera in Almería Province, Spain $\left(36^{\circ} 47^{\prime} 17^{\prime \prime} \mathrm{N} ; 2^{\circ} 42^{\prime} 14^{\prime \prime} \mathrm{W}\right)$. The greenhouse was equipped with ridge and side windows as well as automated fertigation. Plants were grown in soilless cultures in 32-liter bags of perlite (Agroperl GL-3-6, S\&B Industrial Minerals, Berwyn, PA) after direct seed sowing. Fertigation was managed with a programmable system based on the leaching fraction, which was maintained close to $20 \%$. The experiments to evaluate the efficacy of soil solarization and biosolarization were conducted in a 1,144- $\mathrm{m}^{2}$ sloping roof-type polyethylene-covered greenhouse also located at IFAPA Centro La Mojonera. The traditional "enarenado" soil was used in the greenhouse, as it is the most representative of this area.

Temperature data acquisition. Temperatures for all crops were measured inside the bags of perlite and in the greenhouse environment above the plant canopies with $\mathrm{P}-108$ temperature probes for 10-min intervals and recorded with Campbell CR10X dataloggers (Campbell Scientific, Inc., Logan, UT). For solarization experiments, environmental and soil temperatures were measured for the different treatments at a 10 to $15-\mathrm{cm}$ depth and additionally at a 30 to $35-\mathrm{cm}$ depth in the second trial.

Soil-borne inocula survival assessment. The effect of time on inocula contained in bags of perlite was tested based on the ability of the inocula to infect and produce disease symptoms in adult plants. For this purpose, prior to the assessment of inocula survival, a zucchini crop was grown in soilless culture using 32-liter bags of perlite. Three plants per bag were grown in 124 bags of perlite. Ninety-six of the bags of perlite were inoculated with $F$. solani $\mathrm{f}$. sp. cucurbitae as described previously at the 2 to 3 true leaf stage, and 16 bags of perlite were used as noninoculated controls. The plants were maintained in the greenhouse until 60 days after inoculation (dai) when all of the inoculated plants had developed severe leaf wilting or died. Following standard growing practice, the plants were cut and removed at the crown, leaving a portion of the root systems inside the bags of perlite. The bags were left in the greenhouse with the ridge and side windows opened.

For studying the survival of soil-borne inocula, a completely randomized design was used. Four different time intervals during which survival was assessed were considered as treatments. Each treatment was assayed in 24 bags of perlite, and seven noninoculated bags served as controls that were used to evaluate viability decline in propagule survival in vivo over time. After each after-harvest interval, the randomly selected bags were sown with zucchini plants for their evaluation. The bags were grouped in a different part of the greenhouse for better irrigation management. The plants were harvested on 20 July 2012. Bags corresponding to the first treatment were sowed with zucchini seeds of cv. Cónsul in September 2012, as the 2-months-after-harvest ( 2 mah) interval; bags corresponding to the second treatment were sowed in March 2013, 8 months after harvest 
(8 mah); bags corresponding to the third treatment in September 2013, 14 months after harvest (14 mah); and the bags corresponding to the fourth treatment in March 2014, 20 months after harvest (20 mah). At $20 \mathrm{mah}$, plants corresponding to $14 \mathrm{mah}$ were re-evaluated, and these plants are referred to as 14 mah-b. Plants were monitored twice a week for the presence of disease symptoms, and the area under the disease progress curve (AUDPC) was calculated by plotting the number of diseased plants versus time by the trapezoidal method (Madden et al. 2007), and the relative AUDPC (RAUDPC) was expressed as the proportion of the maximum possible AUDPC. In addition, data of the percentage of wilted plants (wilting, W), dead plants (mortality, M) and plants showing crown rot were recorded. After each block was evaluated, $10 \%$ of symptomatic plants were randomly selected for pathogen reisolation.

Fungicide efficacy greenhouse evaluation. Two experiments were conducted to evaluate the efficacy of several chemical and biological products to control the crown and foot rot of zucchini squash. Seeds were directly sowed into bags of perlite during the last week of February 2012 for the first trial and during the first week of May 2012 for the second trial. The experimental design was a randomized complete block with four replicates. Experimental units consisted of three bags of perlite with three plants of cv. Cónsul per bag. Plants were inoculated with the isolate PCl-511 at the 2 to 3 true leaf stage, as previously described. The commercial fungicides were applied to the basal stems of the plants with $50 \mathrm{ml}$ of each product per plant according to the recommended doses listed in the manufacturers' instructions (Table 1). An initial treatment was applied 2 days before inoculation with $F$. solani $\mathrm{f}$. sp. cucurbitae, simulating a preventive treatment, and a second treatment 15 days after the first in both experiments. In addition to fungicides, two fungi were used as biological treatments. The first was a commercial formulation of Trichoderma harzianum, which was inoculated as recommended at the time of sowing with a granular formulation (Trianum-G, T. harzianum strain T-22 spore powder, $1.15 \% \mathrm{w} / \mathrm{w}, 1.5 \times 10^{8}$ spores/g; Koppert B.V., Berkel en Rodenrijs, The Netherlands) of $50 \mathrm{ml} \mathrm{con-}$ taining $2 \mathrm{~g} /$ liter and inoculated again the same day that fungicides were applied with a wettable powder formulation (Trianum-P, T. harzianum strain T-22 spore powder $1.15 \% \mathrm{w} / \mathrm{w}, 1 \times 10^{9}$ spores/g,
Koppert B.V.) with $50 \mathrm{ml}$ at a concentration of $2 \mathrm{~g} /$ liter. Another treatment was applied with the vesicular arbuscular mycorrhizal fungus Rhizophagus irregularis (registered in the International Bank for the Glomeromycota as Glomus intraradices BEG 72 [Blaszk., Wubet, Renker \& Buscot] C. Walker \& A. Shüßler comb. nov.), a fungus isolated from a citrus (Citrus auriantum L.) nursery on the northeastern Spanish coast line (Camprubi and Calvet 1996). The inoculum consisted of rhizosphere, soil, and leek (Allium porrum L.) roots from 1-year-old pot cultures inoculated with the $R$. irregularis strain and grown in calcined montmorillonite clay (Pro's Choice, OilDri Corp., Chicago, IL). Zucchini plants were previously germinated and transplanted to a seedbed with vermiculite and $5 \mathrm{~g}$ of bulk inoculum per plant. Plants were maintained to at least two true leaves, after which they were transplanted to the bags of perlite. In each experiment, a noninoculated control and a nontreated inoculated control were included. To evaluate disease development, plants were monitored twice a week for the presence of disease symptoms. Disease incidence (DI) was calculated as the percentage of symptomatic plants per treatment at the end of the experiment, and the AUDPC and $\mathrm{M}$ were calculated as previously described. During the duration of the experiments, no phytosanitary treatments were applied to avoid interference among products. After experiments concluded, $10 \%$ of symptomatic plants were randomly selected for pathogen reisolation.

Cultivar susceptibility evaluation. To evaluate the susceptibility of zucchini squash cultivars to $F$. solani $\mathrm{f}$. sp. cucurbitae, two trials were conducted: one started during the last week of April 2009 (first trial) and the other during the first week of May 2011 (second trial). The experiments were arranged as a randomized complete block design with three replicates. Each experimental unit within a block consisted of two bags of perlite with three plants per bag, thus there were 18 plants per treatment in each trial. The cultivars studied were 14 of the most commonly used commercial cultivars in the province: Milenio (Semillas Fitó S.A., Barcelona, Spain); Cónsul, Otelo, Platinum, and Senator (Seminis Vegetable Seeds, St. Louis, MO); Capea, Cora, Tosca, and Sinatra (HM-Clause, Davis, CA); Candela (Semillas Fitó S.A.); Cronos (Syngenta Seeds, Basel, Switzerland); Cassiopée (Gautier Semences, Eyragues, France); Natura (Enza Zaden Beheer B.V., Enkhuizen, The Netherlands); and Vesul (Semillas Fitó S.A.)

Table 1. Features and rates of fungicides and fungal antagonists used for greenhouse experiments, and their influence on Fusarium crown and foot rot of zucchini squash plants cultivar Cónsul caused by F. solani f. sp. cucurbitae in greenhouse experiments

\begin{tabular}{|c|c|c|c|c|c|c|c|c|c|c|c|}
\hline \multirow{3}{*}{$\begin{array}{l}\text { Trade name } \\
\text { or treatment }\end{array}$} & \multirow[b]{3}{*}{ Active ingredient } & \multirow[b]{3}{*}{ Manufacturer } & \multirow[b]{3}{*}{ Concentration $(\%)^{\mathbf{u}}$} & \multirow[b]{3}{*}{ Chemical group ${ }^{v}$} & \multirow{3}{*}{$\begin{array}{c}\text { Rates (g or ml } \\
\text { per liter) }{ }^{\mathrm{w}}\end{array}$} & \multicolumn{6}{|c|}{ Disease parameters $^{x}$} \\
\hline & & & & & & \multicolumn{3}{|c|}{ First trial } & \multicolumn{3}{|c|}{ Second trial } \\
\hline & & & & & & DI $(\%)$ & $\mathbf{M}(\%)$ & AUDPC & DI $(\%)$ & $\mathbf{M}(\%)$ & AUDPC \\
\hline Vimar & Metalaxyl & Sarabia S.A. & $25 \% \mathrm{w} / \mathrm{w}$ & Acylalanines & 1.2 & $100 \mathrm{a}$ & $100 \mathrm{a}$ & $626.5 \mathrm{a}$ & $100 \mathrm{a}$ & $75 \mathrm{ab}$ & $529.5 \mathrm{a}$ \\
\hline Previcur & Propamocarb & Bayer CropScience & $60.5 \% \mathrm{w} / \mathrm{v}$ & Carbamates & 1.5 & $100 \mathrm{a}$ & $97.2 \mathrm{a}$ & $567 \mathrm{a}$ & $100 \mathrm{a}$ & $86.1 \mathrm{a}$ & $595 \mathrm{a}$ \\
\hline Octagon & Prochloraz & BASF & $45 \% \mathrm{w} / \mathrm{v}$ & Imidazoles & 3 & $0 \mathrm{~b}$ & $0 \mathrm{~b}$ & ob & $0 \mathrm{~b}$ & ob & ob \\
\hline Kemdazim & Carbendazim & Agroproser S.L. & $50 \% \mathrm{w} / \mathrm{w}$ & Benzimidazoles & 0.75 & ob & ob & Ob & Ob & ob & Ob \\
\hline Terrazole & Etridiazole & Dow AgroSicences & $48 \% \mathrm{w} / \mathrm{v}$ & 1,2,4-thiadiazoles & 2 & $97.2 \mathrm{a}$ & $86.1 \mathrm{a}$ & $640.5 \mathrm{a}$ & $100 \mathrm{a}$ & $100 \mathrm{a}$ & $758.5 \mathrm{a}$ \\
\hline Trotis & Pencycuron & Bayer CropScience & $25 \% \mathrm{w} / \mathrm{v}$ & Phenylureas & 5 & $97.2 \mathrm{a}$ & $69.4 \mathrm{ab}$ & $548.5 \mathrm{a}$ & $100 \mathrm{a}$ & $88.9 \mathrm{a}$ & $593 a$ \\
\hline Topsin & Thiophanate-Methyl & Bayer CropScience & $70 \% \mathrm{w} / \mathrm{v}$ & Thiophanates & 1 & $2.8 \mathrm{~b}$ & $\mathrm{Ob}$ & $7 \mathrm{~b}$ & ob & Ob & ob \\
\hline Moncut & Flutolanil & Massó & $50 \%$ w/w & Phenyl-benzamides & 1 & $100 \mathrm{a}$ & $75 \mathrm{a}$ & $545.5 \mathrm{a}$ & $100 \mathrm{a}$ & $88.9 \mathrm{a}$ & $597 \mathrm{a}$ \\
\hline Trianum & $\begin{array}{l}\text { Trichoderma } \\
\text { harzianum } \\
\text { Strain T22 }\end{array}$ & Koppert B.V & $1.25 \% \mathrm{w} / \mathrm{w}$ & - & 2 & $97.2 \mathrm{a}$ & $88.9 a$ & $676.5 \mathrm{a}$ & $100 \mathrm{a}$ & $97.2 \mathrm{a}$ & $722 \mathrm{a}$ \\
\hline R. irregularis & $\begin{array}{l}\text { Rhizophagus } \\
\text { irregularis } \\
\text { Strain BEG } 72\end{array}$ & - & - & - & - & $100 \mathrm{a}$ & $100 \mathrm{a}$ & $733.5 \mathrm{a}$ & $100 \mathrm{a}$ & $97.2 \mathrm{a}$ & $882 \mathrm{a}$ \\
\hline Control $+{ }^{\mathrm{y}}$ & - & - & - & - & - & $100 \mathrm{a}$ & $91.7 \mathrm{a}$ & $676.5 \mathrm{a}$ & $100 \mathrm{a}$ & $86.1 \mathrm{a}$ & $627 a$ \\
\hline Control - ${ }^{\mathrm{z}}$ & - & - & - & - & - & $0 \mathrm{~b}$ & Ob & Ob & $0 \mathrm{~b}$ & Ob & $0 \mathrm{~b}$ \\
\hline
\end{tabular}

u Percentage of active ingredient in the product formulation: w/w = weight/weight; w/v = weight/volume.

b Chemical group according to Fungicide Resistance Action Committee, FRAC Code List 2013.

w Doses were applied to the crown of the plants according to manufacturer's recommendations and legislation. A first treatment was applied two days before the inoculation with the isolate PCl-511 and a second applied 13 days later.

x Disease parameters were evaluated twice a week on the basis of a 0 to 2 rating scale for the period of the trials, and are expressed as percentages of the total plants. $\mathrm{DI}=$ disease incidence, $\mathrm{M}=$ mortality, $\mathrm{AUDPC}=$ area under disease progress curves assessed by plotting the number of diseased plants per bag versus time, with the trapezoidal method (Madden et al. 2007). Values in columns followed by different letter indicate significant differences $(P \leq 0.05)$.

y Inoculated control not treated with any product.

z Non-inoculated control not treated with any product. 
Seeds were directly sowed in the bags, and plants were inoculated at the 2 to 3 true leaf stage, as previously described. Plants were monitored twice a week for the presence of disease symptoms. DI, M, and the AUDPC were calculated per cultivar as previously described. After the experiments concluded, $10 \%$ of the symptomatic plants were randomly selected for pathogen reisolation.

Soil solarization and biosolarization. For the efficacy evaluation of soil solarization and biosolarization in "enarenado" soil, viability of propagules of $F$. solani $\mathrm{f}$. sp. cucurbitae contained in a portion of soil was assessed after being exposed to 6-week solarization periods in a greenhouse in the summers of 2012 and 2013. For preparing infested soil samples, methodology was adapted from Cebolla and Maroto (2005). Two hundred milliliters of a conidial suspension were transferred to $200 \mathrm{~g}$ of sterile talc to promote the transformation of conidia and mycelia to chlamydospores due to desiccation. After 17 days, the dried talc was added to 3.36 liters of a blend containing $33 \%$ siliceous sand, 33\% natural sandy loam soil, and 33\% peat moss (Comercial Projar S.A., Valencia, Spain) that was previously filtered through a \#20 sieve (840- $\mu \mathrm{m}$ openings) and autoclaved for $1 \mathrm{~h}$ at $121^{\circ} \mathrm{C}$ and $1 \mathrm{~atm}$ for 3 consecutive days. The mixture was then thoroughly homogenized. Samples were prepared by placing $40 \mathrm{ml}$ of this mixture into polyester and polypropylene $100-\mu \mathrm{m}$ mesh sacks and sealed with tie wraps. Samples were then buried in the different blocks at two different depths, 10 to $15 \mathrm{~cm}$ and 30 to $35 \mathrm{~cm}$ respectively. In addition, 24 sample bags were conserved at 4 to $8^{\circ} \mathrm{C}$ to serve as controls: 12 samples to assure the viability of the fungus and the detection method and another 12 soil samples without the addition of the pathogen.

Solarization and biosolarization were performed with a factorial design with two factors (disinfestation treatment and depth) and two blocks. Each block was composed of three treatments (solarization, biosolarization, and a nonsolarized control) and the two depths, 10 to $15 \mathrm{~cm}$ and 30 to $35 \mathrm{~cm}$. Each experimental unit consisted of a $5 \times 10-\mathrm{m}$ plot composed of six subsamples per depth and treatment. Solarization and biosolarization were performed during 45-day periods by completely closing the ridge and side windows of the greenhouse and covering the different $50-\mathrm{m}^{2}$ plots with transparent $50-\mu \mathrm{m}$-thick polyethylene plastic. Control plots were left uncovered. Biosolarization was conducted by adding organic matter consisting of fresh pepper plant debris at $5.4 \mathrm{~kg} / \mathrm{m}^{2}$ and $5 \mathrm{~kg} / \mathrm{m}^{2}$ during the first and second years, respectively. Organic matter in the second year was reduced due to European and local limitations on nitrogen applications to soil. The soil sand covering was removed prior to the addition of organic matter, which was homogenized with a rototiller, and then the sand was redistributed before irrigating with water at 60 liters $/ \mathrm{m}^{2}$.

After the solarization period, soil samples were recovered from soil for colony-forming units (CFU) quantification. Propagule viability was assessed by suspending a portion of the soil samples contained in the bags in Komada's semiselective medium. Fifteen milliliters of Komada medium (Komada 1975) cooled to $50^{\circ} \mathrm{C}$ were poured in 90-mm Petri dishes, and then an aliquot of approximately 30 to $35 \mathrm{mg}$ of each soil subsample was transferred and dispersed by gentle rotation before the medium solidified (Tello et al. 1991). Three replicates per soil subsample were assayed. Plates were incubated at $25^{\circ} \mathrm{C}$, as previously described, and after 3 to 7 days of incubation, all the colonies were counted and checked to verify that they corresponded to $F$. solani, and a concentration of CFU per gram was estimated.

Statistical analyses. Kruskal-Wallis nonparametric analyses of variance (ANOVA) tests were conducted for each of the experiments, of which the percentage of symptomatic plants per treatment (DI), mortality rate (M), AUDPC, and RAUDPCs were analyzed with Statistix 9 (Analytical Software, Tallahassee, FL) due to data nonnormality and variance heterogeneity. The different repetitions of the experiments were included in the model and assayed for differences. In cases where ANOVA revealed no significant differences between experiments, data were pooled prior to analyses. For the solarization and biosolarization experiments, a Kruskal-Wallis ANOVA was performed by comparing the number of CFU per gram estimated per treatment. In all cases, if ANOVA results were significant for main effects, treatment means were compared using all-pairwise comparison tests $(P \leq 0.05)$.

\section{Results}

Pathogen survival assessment in bags of perlite. During the summer months, at $2 \mathrm{mah}$, temperatures ranged from 17.4 to $47.8^{\circ} \mathrm{C}$ with a mean of $29.7^{\circ} \mathrm{C}$ in the greenhouse environment, and from 23.8 to $42.5^{\circ} \mathrm{C}$ with a mean of $31.9^{\circ} \mathrm{C}$ inside the bags of perlite. Means of the maximum daily temperatures achieved were $41.7^{\circ} \mathrm{C}$ in the greenhouse environment and $38.1^{\circ} \mathrm{C}$ in the substrates. Among plants, $97.2 \%$ showed disease symptoms, and, subsequently, $70.8 \%$ of the plants were dead. In the control bags, $14.3 \%$ of the plants showed disease symptoms at the end of the cropping system.

At 8 mah, temperatures ranged from 8.6 to $39.8^{\circ} \mathrm{C}$ with a mean of $17.5^{\circ} \mathrm{C}$ in the greenhouse environment, and from 10 to $36.4^{\circ} \mathrm{C}$ with a mean of $19.5^{\circ} \mathrm{C}$ in the substrate bags. Means of the maximum daily temperatures achieved were $27.8^{\circ} \mathrm{C}$ in the greenhouse environment and $24.2{ }^{\circ} \mathrm{C}$ in the substrates. In this after-harvest interval, $91.7 \%$ of the plants showed disease symptoms, resulting in $87.5 \%$ plant death after 71 days of growth. The incidence in this period was slightly lower than that at $2 \mathrm{mah}$; nevertheless, this decrease was not statistically significant. In the control bags, $95.2 \%$ of the plants remained asymptomatic, and $4.8 \%$ of the plants showed leaf wilting and crown rot.

The following spring months (March to June) and the summer months (June to September) then comprised 14 mah. During the spring months, temperatures in the greenhouse environment ranged from 8.6 to $44.9^{\circ} \mathrm{C}$ with a mean of $22.8^{\circ} \mathrm{C}$, and from 16.1 to $42.7^{\circ} \mathrm{C}$ with a mean of $26.6^{\circ} \mathrm{C}$ in the substrate bags. Means of the maximum daily temperatures achieved were $34.6^{\circ} \mathrm{C}$ in the greenhouse environment and $33.6^{\circ} \mathrm{C}$ in the substrates. During the summer months, temperatures in the greenhouse environment ranged from 18.0 to $45.9^{\circ} \mathrm{C}$ with a mean of $29.7^{\circ} \mathrm{C}$, and from 24.7 to $43.9^{\circ} \mathrm{C}$ with a mean of $32.7^{\circ} \mathrm{C}$, in the substrate bags. Means of the maximum daily temperatures achieved were $41.6^{\circ} \mathrm{C}$ in the greenhouse environment and $40.4^{\circ} \mathrm{C}$ in the substrates. After a month of growth, no disease symptoms of Fusarium crown and foot rot were observed in any of the plants. During this crop there was a high outbreak of a newly described virus to this area, Tomato leaf curl New Delhi virus (ToLCNDV, Juárez et al. 2014). The incidence of this virus was very high, affecting all the plants and strongly reducing their development and fitness. This fact could have an implication for the lack of crown and foot rot symptoms detected in these plants, and for this reason bags corresponding to 14 mah were reevaluated together with 20 mah.

At 20 mah, temperatures ranged from 5 to $40.7^{\circ} \mathrm{C}$ with a mean of $16.9^{\circ} \mathrm{C}$ in the greenhouse environment, and from 8.5 to $36.4^{\circ} \mathrm{C}$ with a mean of $18.1^{\circ} \mathrm{C}$ in the substrate bags. Means of the maximum daily temperatures achieved were $25.9^{\circ} \mathrm{C}$ in the greenhouse environment and $21.7^{\circ} \mathrm{C}$ in the substrates. By 79 days after sowing, only $13.8 \%$ of plants showed wilting symptoms for plants corresponding to 14 mah-b and only $1.4 \%$ at 20 mah. After evaluating the crown rot, the number of diseased plants increased from 13.8 to $22.2 \%$ of the plants for 14 mah-b and from 1.4 to $26.3 \%$ of the plants for 20 mah. There was no plant death in the 14 mah-b group or at 20 mah. Control plants showed no disease symptoms. Final DI data are presented in Figure 1.

Statistical analyses did not reveal significant differences between 14 mah-b and 20 mah, but the DI was statistically lower $(P=0)$ than at $2 \mathrm{mah}$ and $8 \mathrm{mah}$. After $8 \mathrm{mah}$, a reduction in disease development was observed. Compared with 2 mah and 8 mah, aerial disease symptoms were delayed at 14 mah and 20 mah. While at 2 mah and 8 mah disease symptoms were first observed 2 weeks after sowing, at 14 mah-b and 20 mah they were observed 9 weeks after sowing (Fig. 2). Consequently, the RAUDPC for 2 mah and 8 mah was significantly higher than the RAUDPC for 14 mah-b and 20 mah (Fig. 1). For 2 mah, 8 mah, 14 mah-b, and 20 mah, the pathogen was successfully recovered from all plants selected for reisolation.

Fungicide efficacy greenhouse evaluation. In the first trial, temperatures in the greenhouse environment ranged from 6.4 to $34.9^{\circ} \mathrm{C}$ with a mean of $18.6^{\circ} \mathrm{C}$, and from 14.3 to $24.5^{\circ} \mathrm{C}$ with a mean of $20.8^{\circ} \mathrm{C}$ in the culture substrates. In the second trial, temperatures 
ranged from 12.5 to $44.1^{\circ} \mathrm{C}$ with a mean of $27.4^{\circ} \mathrm{C}$ in the greenhouse environment, and from 11.9 to $46.1^{\circ} \mathrm{C}$ with a mean of $27.9^{\circ} \mathrm{C}$ in the substrates. Disease symptoms were first observed at 14 and 13 dai for the first and second trials, respectively. Noninoculated controls and plants treated with prochloraz or carbendazim remained asymptomatic (DI $=0 \%$, and only $2.8 \%$ of the plants treated with thiophanatemethyl in the first trial showed disease symptoms. There were no statistical differences among these three treatments. All the inoculated controls showed disease symptoms, and the DI of the rest of the treatments ranged from 97.2 to $100 \%$ (Suppl. Fig. S1), with no statistically significant differences compared with the inoculated controls (Table 1). In both trials, the pathogen was successfully recovered from all plants selected for reisolation.

Cultivar experiments. In the first trial, zucchini squash plants were maintained in the greenhouse for 53 days, during which temperatures ranged from 12.6 to $47.1^{\circ} \mathrm{C}$ with a mean of $25.7^{\circ} \mathrm{C}$ in the greenhouse environment, and from 14.1 to $35.9^{\circ} \mathrm{C}$ with a mean of $27.2^{\circ} \mathrm{C}$ in the

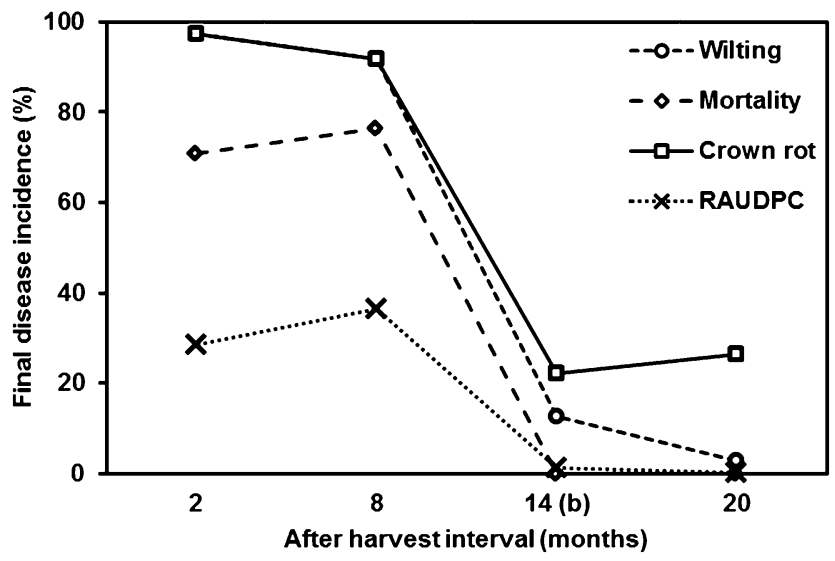

Fig. 1. Final disease incidence curves for each after harvest interval on perlite bags infested with Fusarium solani f. sp. cucurbitae expressed as the percentage of plants showing final wilting, mortality, crown rot and relative area under disease-progress curves (RAUDPC). Data corresponding to 14 (b) months after harvest were obtained by re-evaluating this plot at 20 months after harvest (mah) due to the incidence of ToLCNDV that strongly affected plant growth and development at 14 mah.

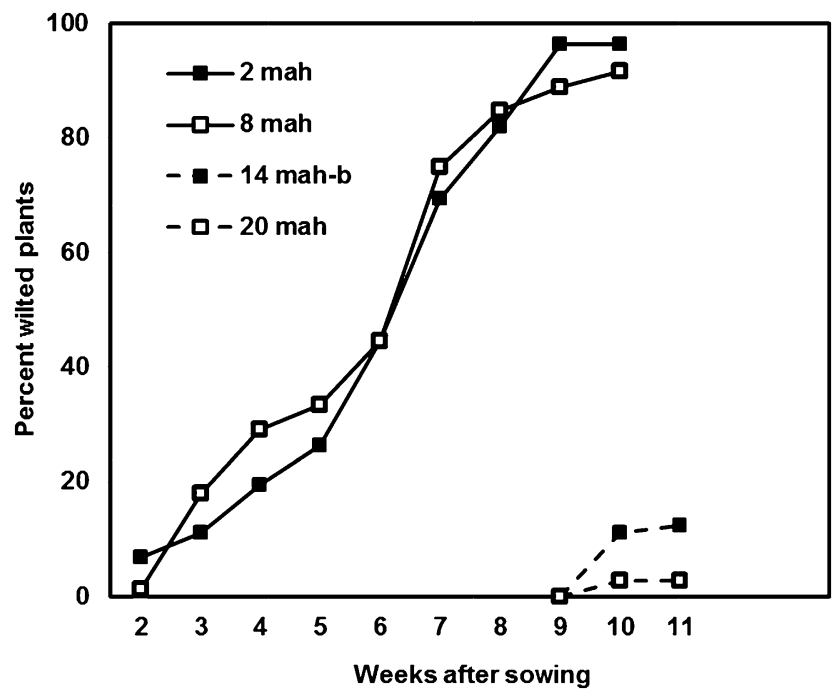

Fig. 2. Disease incidence on zucchini plants grown in previously artificially infested perlite bags for the different after-harvest intervals where bags were left unused expressed as percentage of wilted plants per week after sowing. Data corresponding to 14 mah-b were obtained by re-evaluating this plot at 20 mah due to the incidence of ToLCNDV that strongly affected plant growth and development at 14 mah. substrates. The first disease symptoms were observed at 14 dai. At 18 dai, only the cvs. Otelo, Platinum, Capea, and Tosca remained asymptomatic and, at 21 dai, only the cv. Capea was asymptomatic. At 23 dai, all cultivars had a $100 \%$ DI, with the exceptions of cvs. Cónsul, Otelo, and Platinum, which had a DI of $94.4 \%$, and cv. Capea, which had a DI of $77.8 \%$. These differences were not statistically significant $(P=0.26)$.

In the second trial, plants were kept for 52 days, during which temperatures ranged from 14.1 to $42.9^{\circ} \mathrm{C}$ with a mean of $24.6^{\circ} \mathrm{C}$ in the greenhouse environment, and from 13.6 to $45.3^{\circ} \mathrm{C}$ with a mean of $26.9^{\circ} \mathrm{C}$ in the substrates. In this experiment, disease symptoms where first observed at 12 dai, when every cultivar presented some diseased plants, with the exceptions of cvs. Platinum and Tosca, which remained asymptomatic. Three days later, every cultivar showed disease symptoms in at least some of the plants, and by 41 dai, $100 \%$ of the plants of all cultivars exhibited disease symptoms (Table 2). Statistical analyses revealed differences between the two experiments performed. In both trials, the pathogen was successfully recovered from all plants selected for reisolation.

Solarization and biosolarization. An increase in the temperature of the solarized and biosolarized plots was achieved during both years compared with the control plots, which did not have plastic mulching. In 2012, while control plots had maximum absolute temperatures under $45^{\circ} \mathrm{C}$, solarization treatment resulted in plots measuring a maximum absolute temperature of $52.7^{\circ} \mathrm{C}$, and biosolarization treatment resulted in plots measuring $49.8^{\circ} \mathrm{C}$. In 2013 , two depths were measured. At 10 to $15 \mathrm{~cm}$, the maximum absolute temperature reached $47.1^{\circ} \mathrm{C}$ in the solarization plots and $44^{\circ} \mathrm{C}$ in the biosolarization plots. At 30 to $35 \mathrm{~cm}$, temperatures reached $42.1^{\circ} \mathrm{C}$ in the solarization plots and $41.6^{\circ} \mathrm{C}$ in the biosolarization plots. Control plots had temperatures measuring below $40^{\circ} \mathrm{C}$ at both depths (Table 3 ).

The analysis of the soil samples stored at 4 to $8^{\circ} \mathrm{C}$ as positive controls revealed a high inoculum concentration in the soil contained in the bags with the samples. Propagules were detected in a range of 1.6 to $3.7 \times 10^{3} \mathrm{CFU} / \mathrm{g}$ in 2012 and 1.8 to $4 \times 10^{3} \mathrm{CFU} / \mathrm{g}$ in 2013 . No propagules were detected in the negative controls.

The analysis of the solarized, biosolarized, and control samples compared with the positive controls showed a high reduction in the detection rates of the pathogen. The pathogen could not be detected in any of the solarized or biosolarized samples in 2012, but it was detected in two out of 48 samples at the 30 to $35-\mathrm{cm}$ depth measured in 2013. One sample corresponded to solarization treatment that presented

Table 2. Disease parameter values of 14 zucchini squash cultivars inoculated with $F$. solani f. sp. cucurbitae in greenhouse experiments during the two trials conducted

\begin{tabular}{lccccccc}
\hline & \multicolumn{3}{c}{ First trial } & & \multicolumn{3}{c}{ Second trial } \\
\cline { 2 - 4 } \cline { 6 - 8 } Cultivar & $\mathbf{D I}(\boldsymbol{\%})^{\mathbf{x}}$ & $\mathbf{M}(\boldsymbol{\%})^{\mathbf{y}}$ & $\mathbf{A U D P C}^{\mathbf{z}}$ & & $\mathbf{D I} \mathbf{( \% )}$ & $\mathbf{M}(\boldsymbol{\%})$ & $\mathbf{A U D P C}$ \\
\hline Milenio & 100 & 100 & $393.5 \mathrm{a}$ & & 100 & 100 & $442 \mathrm{ab}$ \\
Consul & 94.4 & 94.4 & $368 \mathrm{ab}$ & & 100 & 94.4 & $396 \mathrm{ab}$ \\
Otelo & 94.4 & 88.9 & $286.5 \mathrm{abc}$ & & 100 & 100 & $401.5 \mathrm{ab}$ \\
Platinum & 94.4 & 61.1 & $196.5 \mathrm{bc}$ & & 100 & 100 & $338.5 \mathrm{~b}$ \\
Senator & 100 & 55.6 & $286 \mathrm{abc}$ & & 100 & 100 & $415 \mathrm{ab}$ \\
Capea & 77.8 & 22.2 & $96.5 \mathrm{c}$ & & 100 & 94.4 & $445.5 \mathrm{ab}$ \\
Cora & 100 & 94.4 & $245.5 \mathrm{abc}$ & & 100 & 100 & $437 \mathrm{ab}$ \\
Tosca & 100 & 100 & $247.5 \mathrm{abc}$ & & 100 & 100 & $365.5 \mathrm{ab}$ \\
Sinatra & 100 & 66.7 & $322 \mathrm{abc}$ & & 100 & 100 & $376.5 \mathrm{ab}$ \\
Candela & 100 & 100 & $352 \mathrm{a}$ & & 100 & 100 & $457.5 \mathrm{a}$ \\
Cronos & 100 & 94.4 & $364.5 \mathrm{a}$ & & 100 & 100 & $451.5 \mathrm{ab}$ \\
Cassiopee & 100 & 100 & $337.5 \mathrm{ab}$ & & 100 & 100 & $418 \mathrm{ab}$ \\
Natura & 100 & 100 & $303.5 \mathrm{abc}$ & & 100 & 100 & $445.5 \mathrm{ab}$ \\
Vesul & 100 & 100 & $306 \mathrm{abc}$ & & 100 & 94.4 & $414.5 \mathrm{ab}$ \\
\hline
\end{tabular}

${ }^{\mathrm{x}} \mathrm{DI}=$ Disease incidence expressed as the percentage of the total number of plants.

${ }^{y} \mathrm{M}=$ Mortality.

${ }^{\mathrm{z}} \mathrm{AUDPC}=$ Area under disease progress curves assessed by plotting the rating on the basis of a 0 to 2 scale versus time, with the trapezoidal method (Madden et al. 2007). Values in columns followed by different letters indicate significant differences $(P \leq 0.05)$. 
a $97.35 \%$ reduction $(77 \mathrm{CFU} / \mathrm{g}$ ), and the other corresponded to biosolarization treatment with a $99.4 \%$ reduction $(17 \mathrm{CFU} / \mathrm{g})$. Even in the control plots, the inoculum was substantially reduced. Two samples in 2012 had estimated pathogen inocula reductions of $99.6 \%$ at 30 to $35 \mathrm{~cm}(9 \mathrm{CFU} / \mathrm{g})$. In 2013 , one sample at 10 to $15 \mathrm{~cm}$ showed a $99.5 \%$ reduction $(12 \mathrm{CFU} / \mathrm{g})$, and two samples at 30 to $35 \mathrm{~cm}$ showed 99.5 and $99.1 \%$ reductions $(12 \mathrm{CFU} / \mathrm{g}$ and $24 \mathrm{CFU} / \mathrm{g}$, respectively; Table 4). Statistical analyses indicated no significant differences in pathogen survival between solarization, biosolarization and the control plots $(P=0.674)$.

\section{Discussion}

Results of the different experiments revealed severe disease development in adult zucchini squash plants grown in bags of perlite, when mean temperatures in the substrates ranged between 20 and $28^{\circ} \mathrm{C}$. These temperatures are optimal for the in vitro growth of F. solani f. sp. cucurbitae (Pérez-Hernández et al., unpublished), and this could explain why in our experiments there was such a rapid development of the disease after the first appearance of symptoms, resulting in the death of a high percentage of the plants. The lack of symptoms in most of the noninoculated plants in our experiments reveals the low aerial dispersal rate of the pathogen, and the success of the basic hygienic measures implemented in this soilless growth system to avoid disease dispersion through the greenhouse.

The experiments performed to study the survival of the fungus in the culture substrates revealed its resistance during July and August, when it was exposed to daily maximum temperatures averaging $38.1^{\circ} \mathrm{C}$. Although the fungus was exposed to maximum temperatures greater than $42^{\circ} \mathrm{C}$, there was no apparent loss of viability. In addition, plants continued to show severe disease symptoms for an additional six months, indicating the survival of a high number of propagules in the substrate bags for a total of eight months after the disease outbreak. At $14 \mathrm{mah}$, a large number of plants were affected by the recently detected Tomato leaf curl New Delhi virus (Juárez et al. 2014). This disease strongly affected plant development and fitness, and could have an implication for the lack of crown and foot rot symptoms detected in these plants. For this reason, at 20 mah we reevaluated the 14 mah specimens, and data corresponding to this group of bags were referred to as 14 mah-b. The presences of symptoms in the 14 mah-b and 20 mah groups indicates that there were likely surviving inocula at 14 mah. For 14 mah-b and 20 mah, aerial disease symptoms were observed in 12.5 and $2.78 \%$ of the plants, respectively. This DI was statistically lower than those observed at 2 mah and 8 mah, revealing an inoculum reduction in the bags of perlite 14 and 20 months after harvesting. An evaluation for crown rot in the 14 mah-b and 20 mah groups revealed necrosis and pathogen reisolation from some of the plants, indicating that some inocula remained; however, the quantity was not high enough to produce wilting after more than 60 days. These results are in agreement with previous observations by Nash and Alexander (1965) which revealed a large decrease in $F$. solani f. sp. cucurbitae survival in artificial soils after 586 days, which is a shorter period than other Fusarium species, which could survive for up to 10 years in sterile soil (Nash and Alexander 1965; Windels et al. 1993). It is important to consider that part of the root systems were left in the bags, as this is common practice in the growing area due to the high cost and difficulty associated with completely removing them from the substrate. This fact could have extended the pathogen's survival, since some reports indicate that root tissue may reduce the effect of adverse soil conditions and provide protection to pathogens (English and Mitchell 1994), aiding the survival of long-lasting structures such as chlamydospores of Fusarium spp. (Sharma 2004; Leslie and Summerell 2007) or oospores of Phytophthora cinnamomi (Jung et al. 2013). Our results indicate that $F$. solani f. sp. cucurbitae is able to survive in the substrates after a disease outbreak, and that inoculum is significantly reduced after 14 months. Crop rotations with nonhost crops may be a good alternative way to avoid this disease. Tomatoes, peppers, eggplants, and beans are important crops commonly cultivated in Almería Province, and can be grown in different crop cycles and conditions under the same type of greenhouse structures. There are therefore many possible combinations that make rotations a viable alternative for growers.

The utilization of cultivars less-susceptible or resistant against certain diseases is a broadly implemented measure, and is recommended for integrated pest management strategies where possible (Jiménez-Díaz and Jiménez-Gascó 2011). In the first of the cultivar susceptibility trials, cultivar Capea appeared to be less susceptible to the disease than the others tested, with a final DI of $77.2 \%$ and $\mathrm{M}$ of $22.2 \%$. However, this result was not repeated in the second experiment, where $100 \%$ of the plants showed disease symptoms. The statistical analyses revealed differences between experiments; however, these differences do not seem to be due to temperature, since mean temperatures in the substrates were similar in both experiments. The other zucchini squash cultivars tested in these

Table 3. Temperature data during the solarization and biosolarization six-week periods in the summers of 2012 and 2013 measured in the different treatments, buried at different depths and exposed to the solarization and biosolarization periods ${ }^{\mathrm{z}}$

\begin{tabular}{|c|c|c|c|c|c|c|c|c|c|c|c|c|}
\hline & \multicolumn{6}{|c|}{ Year 2012} & \multicolumn{6}{|c|}{ Year 2013} \\
\hline & \multicolumn{2}{|c|}{ Mean } & \multicolumn{2}{|c|}{ Maximum mean } & \multicolumn{2}{|c|}{ Absolute maximum } & \multicolumn{2}{|c|}{ Mean } & \multicolumn{2}{|c|}{ Maximum mean } & \multicolumn{2}{|c|}{ Absolute maximum } \\
\hline & $10-15 \mathrm{~cm}$ & $30-35 \mathrm{~cm}$ & $10-15 \mathrm{~cm}$ & $30-35 \mathrm{~cm}$ & $10-15 \mathrm{~cm}$ & $30-35 \mathrm{~cm}$ & $10-15 \mathrm{~cm}$ & $30-35 \mathrm{~cm}$ & $10-15 \mathrm{~cm}$ & $30-35 \mathrm{~cm}$ & $10-15 \mathrm{~cm}$ & $30-35 \mathrm{~cm}$ \\
\hline Solarization & 44.1 & $\mathrm{n} / \mathrm{a}$ & 49.5 & $\mathrm{n} / \mathrm{a}$ & 52.7 & $\mathrm{n} / \mathrm{a}$ & 42.1 & 39.5 & 45.1 & 40.1 & 47.1 & 42.1 \\
\hline Biosolarization & 43.3 & $\mathrm{n} / \mathrm{a}$ & 47.0 & $\mathrm{n} / \mathrm{a}$ & 49.8 & $\mathrm{n} / \mathrm{a}$ & 40.7 & 39.0 & 42.1 & 39.4 & 44.0 & 41.6 \\
\hline Control & 39.5 & $\mathrm{n} / \mathrm{a}$ & 42.4 & $\mathrm{n} / \mathrm{a}$ & 44.5 & $\mathrm{n} / \mathrm{a}$ & 36.9 & 35.9 & 38.3 & 36.2 & 39.8 & 37.9 \\
\hline
\end{tabular}

${ }^{\mathrm{z}}$ Temperatures were measured with Campbell temperature probes P-108 and registered each $10 \mathrm{~min}$ with a Campbell CR10X datalogger. Temperature probes were buried at 10 to $15 \mathrm{~cm}$. In 2013, additional temperature probes were buried at 30 to $35 \mathrm{~cm}$. Mean = mean temperatures for the whole period; Maximum mean $=$ Mean of the maximum daily temperatures; Absolute maximum $=$ Maximum temperature registered for the whole period; $\mathrm{n} / \mathrm{a}=$ not available .

Table 4. Pathogen survival of Fusarium solani f. sp. cucurbitae buried at different depths and exposed to the solarization and biosolarization periods ${ }^{\mathrm{z}}$

\begin{tabular}{|c|c|c|c|c|c|c|c|c|}
\hline & \multicolumn{4}{|c|}{ Year 2012} & \multicolumn{4}{|c|}{ Year 2013} \\
\hline & \multicolumn{2}{|c|}{$10-15 \mathrm{~cm}$} & \multicolumn{2}{|c|}{$30-35 \mathrm{~cm}$} & \multicolumn{2}{|c|}{$10-15 \mathrm{~cm}$} & \multicolumn{2}{|c|}{$30-35 \mathrm{~cm}$} \\
\hline & B1 & $\overline{\mathrm{B} 2}$ & B1 & $\overline{B 2}$ & B1 & $\overline{B 2}$ & $\overline{B 1}$ & B2 \\
\hline Solarization & 0 & 0 & 0 & 0 & 0 & 0 & 0 & 12.8 \\
\hline Biosolarization & 0 & 0 & 0 & 0 & 0 & 0 & 0 & 2.8 \\
\hline Control & 0 & 0 & 1.5 & 1.5 & 0 & 2 & 2 & 4 \\
\hline
\end{tabular}

${ }^{\mathrm{z}}$ Number of CFU/g detected per sample after six-week solarization periods in artificially infested soils buried at 10 to 15 and 30 to $35 \mathrm{~cm}$ depth. Samples with the infested soil were placed in polyester fabric and polypropylene net bags and buried in plots at the start of the periods. Soil analyses were done by dispersing three aliquots of each soil subsample on Komada's medium Petri plates. Values correspond to the average number of colonies counted per gram of soil of the six subsamples included on each replicate. There were not statistically significant differences among treatments $(P=0.675)$. $\mathrm{B}=\mathrm{Block}$. 
experiments were very susceptible to crown and foot rot caused by $F$. solani f. sp. cucurbitae. These results suggest that none of the tested cultivars are effective options for controlling the disease. Therefore, the search for resistant or tolerant zucchini squash accessions should continue due to the aggressive nature of this pathogen to zucchini and other cucurbits, including melon, watermelon, cucumber, and Cucurbita spp. rootstocks (Pérez-Hernández et al., unpublished).

With respect to the fungicide efficacy evaluation, three of the products tested, prochloraz, carbendazim, and thiophanate-methyl, were highly effective at controlling disease up to 40 dai. No disease symptoms were detected in any of the plants treated with these products, with the exception of one plant treated with thiophanate-methyl in the first trial. This efficacy is consistent with previous studies carried out in vitro, where $F$. solani growth was totally inhibited in culture media supplemented with carbendazim and thiophanate-methyl (Ben Salem et al. 2011; Sultana and Ghaffar 2010). However, this is the first study to demonstrate the efficacy of these fungicides against this disease under greenhouse conditions with adult plants. In contrast, the other tested fungicides and biological products showed no significant differences in disease severity compared with the nontreated inoculated controls, suggesting that they are ineffective for the control of Fusarium crown and foot rot of zucchini squash. The use of chemical products is subjected to constant regulatory modifications. Recently, the use of carbendazim has been banned in the European Union and the United States, among other countries. Prochloraz and thiophanate-methyl are currently included in the Annex 1 list of permitted products in the European Union (Regulation 1107/2009/EC). Both products are currently labeled for their use in Spain and other countries in the European Union to control diseases caused by $F$. oxysporum in watermelon, cucumber, and melon. However, its use is not currently allowed in zucchini squash, probably because of the lack of other Fusarium diseases affecting it in Spain. Our results demonstrate the interest of the registration of prochloraz and thiophanate-methyl for the control of Fusarium crown and foot rot of zucchini squash, as they are used in several other cucurbits.

Soil solarization and biosolarization effectiveness in greenhouses depends on a great variety of factors, such as incoming solar radiation, soil humidity, and temperatures reached. In Almería Province, these techniques are frequently performed in summer, when the high temperatures are difficult for the cultivation in the greenhouses of most horticultural crops. Our experiments were performed in the months of July and August, keeping the greenhouse completely sealed for 45 days. The analysis of the samples exposed to solarization, biosolarization, and the nontreated control, revealed that closing the greenhouse windows during the hottest months even without the addition of a plastic mulch had a significant impact on the pathogen's survival, and that temperatures reached in the soil were high enough to reduce the population of $F$. solani f. sp. cucurbitae. In addition, the application of plastic mulch increased the temperatures measured in the soil compared with the nontreated control. However, the effect on pathogen's survival of this temperature increase could not be validated with these experiments, in contrast to what was previously observed in similar experiments with other pathogens such as $F$. oxysporum ff. sp. radicis-lycopersici and melonis, and Pythium aphanidermatum (Pérez et al. 2014).

Several measures can be applied for the control of crown and foot rot of zucchini squash caused by $F$. solani f. sp. cucurbitae. We tested several control strategies including host resistance, chemical, and biological control, and soil solarization and biosolarization. Based on our results, the most promising management strategy would be the application of prochloraz or thiophanate-methyl to the stems of the plants. However, because their use is not currently allowed in zucchini squash, manufacturers should consider registering them for their use in this crop. At least two years of crop rotation without cucurbits is also expected to be effective. Although soil solarization and biosolarization have proven to reduce inoculum in the soil, additional research is needed to document their efficacy to control the disease in greenhouse conditions.

\section{Acknowledgments}

This work was financed by projects INIA RTA2010-00044-00-00 (Ministerio de Agricultura, Alimentación y Medio Ambiente, Spain) and Transforma Protected Horticulture TRA201300.11, financed with the European Social Fund (ESF) and
European Regional Development Fund (ERDF). A. Pérez-Hernández was supported by a pre-doctoral fellowship financed by the INIA. We thank Dr. C. Cherk Lim for review of the manuscript and Dr. C. Calvet-Pinós (Instituto de Investigación y Tecnología Agroalimentarias, IRTA Cabrils) for providing the Rizhophagus irregularis inoculum. We also thank Ms. J. Ros for her valuable technical assistance.

\section{Literature Cited}

Armengol, J., José, C., Moya, M., Sales, R., Vicent, A., and García-Jiménez, J. 2000. Fusarium solani f. sp. cucurbitae race 1, a potential pathogen of grafted watermelon production in Spain. EPPO Bull. 30:179-183.

Bello, A., López-Pérez, J. A., Díaz, L., Sanz, R., and Arias, M. 1999. Biofumigation and local resources as methyl bromide alternatives. Abstracts of the 3rd Int. Workshop: Alternatives to Methyl Bromide for the Southern European Countries. Crete, Greece.

Ben Salem, I., Boughalleb, N., Souli, M., Selmi, S., and Romdhani, M. E. 2011 Fungitoxicity of some fungicides against to pathogens responsible of olive trees decline in the Chebika's area in Tunisia. Res. Plant Biol. 1:30-39.

Bonachela, S., Acuña, R., and Magán, J. 2008. Capítulo II: Sustratos inertes. Caracterización física. Oxigenación de los sustratos. Pages 27-36 in: Relaciones Hídricas y Programación de Riego en Cultivos Hortícolas en Sustratos. E. Medrano, M. C. Sáncez-Guerrero, P. Lorenzo, and F. Alonso, eds. IFAPA, El Ejido, Spain.

Boughalleb, N., and El Mahjoub, M. 2006. In vitro determination of Fusarium spp infection of watermelon seeds and their localization. Plant Pathol. J. 5:178-182.

Boughalleb, N., Tarchoun, N., El Mbarki, A., and El Mahjoub, M. 2007. Resistance evaluation of nine cucurbit rootstocks and grafted watermelon (Citrullus lanatus $\mathrm{L}$.) varieties against Fusarium wilt and Fusarium crown and root rot. J. Plant Sci. 2: 102-107.

Bourbos, V. A., Skoudridakis, M. T., Darakis, G. A., and Koulizakis, M. 1997 Calcium cyanamide and soil solarization for the control of Fusarium solani f. sp. cucurbitae in greenhouse cucumber. Crop Prot. 16:383-386.

Camprubi, A., and Calvet, C. 1996. Isolation and screening of mycorrhizal fungi from citrus nurseries and orchards and inoculation studies. HortScience 31:366-369.

Cebolla, V., and Maroto, J. V. 2005. La solarización con restos de brasica spp. vs. bromuro de metilo y otros fumigantes químicos para desinfectar el suelo. Phytoma 172:66-70.

Champaco, E. R., Martyn, R. D., and Miller, M. E. 1993. Comparison of Fusarium solani and $F$. oxysporum as causal agents of fruit rot and root rot of muskmelon. HortScience 28:1174-1177.

Chellemi, D. O., Olson, S. M., Mitchell, D. J., Secker, I., and McSorley, R. 1997. Adaptation of soil solarization to the integrated management of soilborne pests of tomato under humid conditions. Phytopathology 87:250-258.

Elmore, C. L., Stapleton, J. J., Bell, C. E., and DeVay, J. E. 1997. Soil solarization: A nonpesticidal method for controlling diseases, nematodes, and weeds. Div. of Agric. and Nat. Resources Publ. 21377. Univ. of Calif., Oakland, CA.

English, J. T., and Mitchell, D. J. 1994. Host roots. Pages 34-64 in: Epidemiology and Management of Root Diseases. C. L. Campbell, and D. M. Benson, eds. Springer-Verlag, Berlin, Germany.

Gómez, J., Serrano, Y., Pérez, A., Porcel, E., Gómez, R., and Aguilar, M. I. 2014 Fusarium solani f. sp. cucurbitae, affecting melon in Almería Province, Spain. Australas. Plant Dis. Notes 9:136.

Gómez, J. M., Guerra-Sanz, M. C., Sánchez-Guerrero, Y., Serrano, Y., and Melero-Vara, J. M. 2008. Crown rot of zucchini squash caused by Fusarium solani f. sp. cucurbitae in Almería Province. Plant Dis. 92:1137.

González-Torres, R., Melero-Vara, J. M., Gómez-Vázquez, J. M., and JiménezDíaz, R. M. 1993. The effects of soil solarization and soil fumigation on Fusarium wilt of watermelon grown in plastic houses in south-eastern Spain. Plant Pathol. 42:858-864.

Jiménez-Díaz, R. M., and Jiménez-Gascó, M. M. 2011. Integrated management of Fusarium wilt diseases. Pages 177 to 215 in: Control of Fusarium Diseases. F. M. Alves-Santos, and J. J. Díez, eds. Research Signpost, Kerala, India.

Juárez, M., Tovar, R., Fiallo-Olivé, E., Aranda, M. A., Gosálvez, B., Castillo, P., Moriones, E., and Navas-Castillo, J. 2014. First detection of tomato leaf curl New Delhi virus infecting zucchini in Spain. Plant Dis. 98:857-858.

Jung, T., Colquhoun, I. J., and Hardy, G. E. St. J. 2013. New insights into the survival strategy of the invasive soilborne pathogen Phytophthora cinnamomi in different natural ecosystems in western Australia. For. Pathol. 43:266-288.

Katan, J. 1981. Solar heating (solarization) of soil for control of soilborne pests. Annu. Rev. Phytopathol. 19:211-236.

Komada, H. 1975. Development of a selective medium for quantitative isolation of Fusarium oxysporum from natural soil. Rev. Plant Prot. Res. 8:114-125.

Leslie, J. F., and Summerell, B. A. 2007. The Fusarium Laboratory Manual Blackwell Publ., Ames, IA.

Madden, L. V., Hughes, G., and van den Bosch, F. 2007. The Study of Plant Disease Epidemics. American Phytopathological Society, St. Paul, MN.

Martínez, M. A., Martínez, M. C., Bielza, P., Tello, J., and Lacasa, A. 2011. Effect of biofumigation with manure amendments and repeated biosolarization on Fusarium densities in pepper crops. J. Ind. Microbiol. Biotechnol. 38:3-11.

Matheron, M. E., and Porchas, M. 2010. Evaluation of soil solarization and flooding as management tools for Fusarium wilt of lettuce. Plant Dis. 94: $1323-1328$. 
Matta, A., and Garibaldi, A. 1981. Malattie delle piante ortensi. Edagricole, Bologna, Italy.

Mehl, H. L., and Epstein, L. 2007. Identification of Fusarium solani f. sp. cucurbitae race 1 and race 2 with PCR and production of disease-free pumpkin seeds. Plant Dis. 91:1288-1292.

Messiaen, C. M., Blancard, D., Rouxel, F., and Lafon, R. 1995. Enfermedades de las hortalizas. Ediciones Mundi-Prensa, Madrid.

Nash, S. M., and Alexander, J. M. 1965. Comparative survival of Fusarium solani f. sp. cucurbitae and F. solani f. phaseoli in soil. Phytopathology 55:963-966.

Núñez-Zofio, M., Larregla, S., and Garbisu, C. 2011. Application of organic amendments followed by soil plastic mulching reduces the incidence of Phytophthora capsici in pepper crops under temperate climate. Crop Prot. 30:1563-1572.

Paternotte, S. J. 1987. Pathogenicity of Fusarium solani f. sp. cucurbitae race 1 to courgette. Neth. J. Plant Pathol. 93:245-252.

Pérez, A., Martín, E., Giménez, M., Fernández, M., and Gómez, J. 2014. Eficacia de la solarización y la biosolarización del suelo en el control de patógenos en cultivos enarenados. Vida Rural 378:24-30.

Porcel, E. 2013. Caracterización Morfológica y Patogénica de Aislados de Fusarium solani f. sp. cucurbitae. Proyecto de Fin de Carrera, Universidad de Almería, Spain.

Roberti, R., Veronesi, A., and Flamigni, F. 2012. Evaluation of microbial products for the control of zucchini foot and root rot caused by Fusarium solani $\mathrm{f}$. sp. cucurbitae race 1. Phytopathol. Mediterr. 51:317-331.
Sharma, P. D. 2004. Plant Pathology. Rajsons Printers, New Delhi, India.

Sultana, S., and Ghaffar, A. 2010. Effect of fungicides, microbial antagonists and oilcakes in the control of Fusarium solani, the cause of seed rot, seedling and root infection of bottle gourd, bitter gourd and cucumber. Pak. J. Bot. 42: 2921-2934.

Tello, J., Vares, F., and Lacasa, A. 1991. Pages 39-77 in: Análisis de las muestras. Manual de Laboratorio: Diagnóstico de Hongos, Bacterias y Nematodos Fitopatógenos. Ministerio de Agricultura, Pesca y Alimentación, Madrid, Spain.

Valera, D. L., Belmonte, L. J., Molina, F., and López, A. 2014. Los Invernaderos de Almería: Análisis de su Tecnología y Rentabilidad.Cajamar Caja Rural, Almería, Spain.

Vallance, J., Déniel, F., Le Floch, G., Guérin-Dubrana, L., Blancard, D., and Rey, P. 2011. Pathogenic and beneficial microorganisms in soilless cultures. Agron. Sustain. Dev. 31:191-203.

Windels, C. E., Burnes, P. M., and Kommedahl, T. 1993. Fusarium Species Stored on Silica Gel and Soil for Ten Years. Mycologia 85:21-23.

Wolosin, R. T. 2008. El Milagro de Almería, España: A Political Ecology of Landscape Change and Greenhouse Agriculture. Graduate Theses, Dissertations and Professional Papers 366. University of Montana, Missoula, MT

Zitter, T. A., Hopkins, D. L., and Thomas, C. E. 1996. Compendium of Cucurbit Diseases. American Phytopathological Society, St. Paul, MN. 